\title{
Decolonising the concept of the Trinity to decolonise the religious education curriculum
}

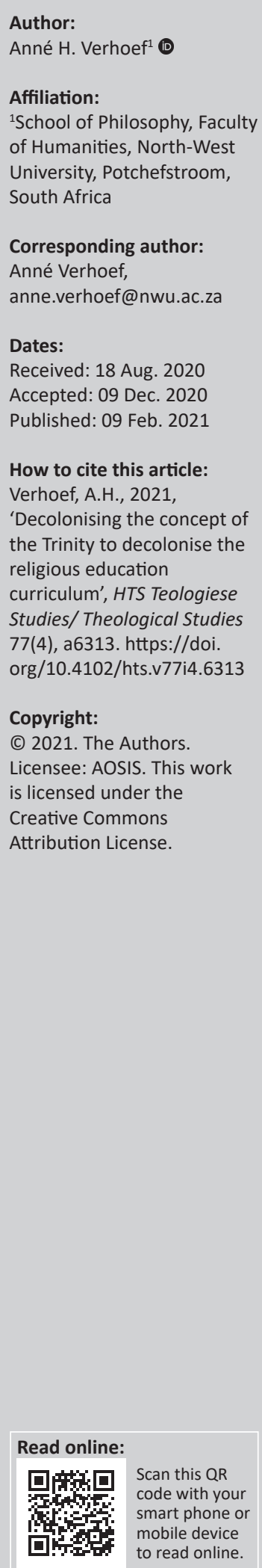

This article brings into perspective the need to decolonise the concept of the Trinity (as the specific doctrine and Christian name of God) as a crucial step in decolonising the religious education curriculum. It discusses the concept of decolonisation and its applicability to religious education, specifically Christianity, within higher education (e.g. in Teacher Education Programmes) in the South African context. God as the Trinity has throughout the history of Atlantic slavery and colonialism been employed to legitimise colonial rule and it, therefore, needs to be decolonised. To decolonise the concept of the Trinity is, however, highly problematic, as the historic relation between Christianity and African traditional religions (ATRs) indicates. Decolonising the concept of the Trinity can quickly develop into a tension between a position of either continuity or discontinuity (of ATR with Christianity).

Contribution: This article argues for an alternative approach for the decolonisation of the concept of the Trinity, namely to allow for the deconstruction of the concept of the Trinity, and by implication of other concepts - like decolonisation and religion - as well. This approach is proposed to develop more openness and playfulness with regard to religious beliefs in general. I argue that this may provide a hopeful, open and just vision of life which should be part of the decolonised religious education curriculum.

Keywords: Trinity; decolonisation; religious education; theology; deconstruction; African Traditional Religions; curriculum.

\section{Introduction}

The resistance of African Christian theology against the colonising doctrine of the Trinity (Conradie \& Sakupapa 2018) has various implications for decolonising the religious education curriculum. ${ }^{1}$ The need to decolonise the concept of the Trinity itself becomes quite apparent. To explore this feature, the definition of decolonisation and its applicability to religious education, especially in the South African higher education context, first needs to be clarified. The contested nature, as well as the importance of the concept of decolonisation, will thereby be discussed as applied to the religious education curriculum (included as a compulsory module in most Teacher Education Programmes in South Africa) that engages, amongst others, with Christianity.

The Trinity is one of the most problematic aspects of African theology (Vahakangas 2002). The reason is that the concept of the Trinity - as the name of the Christian God (see section 'the concept of the Trinity: colonising and oppressive, or decolonising and redemptive?') - became associated with Western missionaries and colonial forces of occupation, oppression and exploitation. African traditional religions (ATRs) and African theology ${ }^{2}$ often find themselves in conflict with the doctrine of the Trinity (Kombo 2007; Mbiti 2013), with Christianity and Christian churches being criticised for being a white man's institution and in service of the colony. Fanon (2017), for example, noted:

$[T]$ he church in the colonies is a white man's Church, a foreigner's Church. It does not call the colonised to the ways of God, but to the ways of the white man, to the ways of the master, the ways of the oppressor. (p. 69) ${ }^{3}$

1.'Religious education' denotes the compulsory module that students and teachers have to enrol for in Teacher Education Programmes. Du Preez and Simmonds (2020:2) explained that the typical content include '...the six main religions in South Africa (i.e. Judaism, Christianity, Islam, Hinduism, Buddhism and African Religion) as well as discussions of several hegemonic discourses and phenomena related to the study of religion. These include, but are not limited to, fundamentalism, secularism and human rights in the context of religion, in addition to more general explorations of cultural diversity in education'.

2.I acknowledge that ATR and African theology are not homogeneous units, but include rather complex and diverse voices. In this article, I attempt to identify and discuss some general trends within these 'movements' without dismissing the exceptions. Furthermore, the concept of religion is not so neatly applicable to African spirituality and ways of living It has a Western and Christian history, connotation concept of religion is not so neatly applicable to African spirituality and ways of living. It has a Western and Christian history, connotation and association that cannot be ignored. When one speaks of ATR's as religions, it is limiting, because 'religion' does not normally refe to the broader African communal lifestyle or 'ancestor-communal-centred' lifestyle. Although I acknowledge this shortcoming, I retain the concept 'religion' as it is a term widely accepted and used. The concern I raise in this article is not directly related to this specific issue. The problem of the concept of religion links to the problem and argument of this article in the sense that decolonisation should take place of our most fundamental terminology - like the concept of the Trinity - through a deconstruction thereof.

3.It is the Christian Church's baptism in the name of the Father, Son and Holy Spirit, which links the church most explicitly to the concept of the Trinity. 
Steve Biko (2017:64) shares this concern and writes about the 'terrible role' colonial education and religion played in creating a 'false understanding' of the black self and of God. The problem is that the concept of the Trinity has throughout the history of colonialism been employed 'to legitimise colonial rule and to suppress indigenous spirituality' (Conradie \& Sakupapa 2018:51). The focus of this article is thus on the need and method to decolonise the concept of the Trinity in an effort to decolonise the religious education curriculum. The argument is that in order to decolonise the religious education curriculum, the concept of the Trinity should be decolonised.

The decolonisation of the concept of the Trinity has been approached in different ways (Conradie \& Sakupapa 2018; Sakupapa 2018) ${ }^{4}$ and also the subsequent question of how to transform theological knowledge (eds. Venter \& Tolmie 2012). One approach is to reinterpret the name of God - as Trinity - in line with ATR's concept of God. This approach argues for a continuity within ATRs and African theology with Christianity. Another approach to the decolonising of the concept of the Trinity is to reject it as colonial and promote ATR's concepts of God as an alternative. This approach favours a discontinuity between ATRs and African theology with Christianity. Another option is to argue for a reinterpretation of the concept of the Trinity - as a 'decolonising doctrine' and not as an oppressive and colonising one (Conradie \& Sakupapa 2018). This, however, seems at first like another strong continuity approach or even a type of discontinuity approach (that favours Christianity in such a strong way that the concept of the Trinity completely dominates all interpretations of ATR's concepts of God). If this is the case, this approach lacks real decolonisation.

In this article I propose an alternative approach to the decolonising of the concept of the Trinity and argue for the deconstruction of the concept and (by implication) the doctrine of the Trinity. This requires a sensitivity for poststructuralist and deconstructive critique, but also an imaginative and creative openness to move away from all dogmatism (Verhoef 2019:7-8). I motivate this approach with the intended outcome of religious freedom, openness and playfulness. Such an approach celebrates diversity within religious education, with a sensitivity for the constructive and destructive potential of religions' power in general.

\section{Decolonisation and religious education}

Decolonisation is described by many scholars as a contested concept (Du Preez et al. 2016:3; Le Grange 2018:7). It has different meanings in different discourses. It is a term that is in becoming, without fixity, and it entails different processes that are in themselves dynamic. One can, however, narrow down

4.Conradie and Sakupapa's 2018 article, 'Decolonising the Doctrine of the Trinity' or 'The Decolonising Doctrine of the Trinity'? is seminal in this regard. This article will 'The Decolonising Doctrin of the Trinity'? is seminal in this regard. This article will rely and build upon Conradie and Sakupapa's work to a large extent and will specifically apply it to the decolonisation of religious education. It is, therefore, not per se a critique of Conradie and Sakupapa's article, although some critique is given. In the same vein this article is not a critical discussion of ATR or African theology, but rather an attempt to see how it links to possibilities to decolonising the religion education curriculum. the meaning of decolonisation to the undoing of colonialism. In other words, it is the attempt to end the colony and colonisation in all its forms (Verhoef \& Kruger 2019:113). Thus, the firstgeneration colonialism entailed the conquering of the physical spaces and bodies of the colonised, whilst second-generation colonialism was concerned with the colonisation of the mind (Odora-Hoppers \& Richards 2011:7). The first-generation decolonisation accordingly entailed the emancipation of bodies and spaces from the colonisers, whereas the second-generation decolonisation attempted to overcome the whole legacy of colonialism, to 'decolonise the intellectual landscape of the country [...] and, ultimately, [to] decolonise the mind of the formerly colonised' (Oelofsen 2015:131). Decolonisation is, therefore, the undoing of the colony that still exists within the 'underlying structures of oppression and injustice' (Heleta 2016:1). These structures are embedded within our (South African, but also in other parts of the world) whole society, our way of thinking, our intellectual landscape, our way of being and in our religious language, symbols and beliefs - and of course within our religious education curriculum.

It is within this all encompassing understanding of coloniality that is embedded within all structures of society that decolonisation is understood as the 'critical awareness of the logic of coloniality (the colonial matrix of power); it is a critique of coloniality, it resists expressions of coloniality and takes actions to overcome coloniality' (Le Grange 2018:9). This article is concerned with what this means for the religious education curriculum, especially in the South African higher education context such as the compulsory Teachers Education Programme. Whilst this article focuses primarily on Christianity and on higher education in South Africa, the implications for decolonisation of the religious education curriculum are applicable to other contexts, other parts of the world and other religions as well.

The South African higher education context is challenged by different stakeholders to decolonise, because the curriculum at universities in South Africa remains largely Eurocentric and continues to reinforce white and Western dominance and privilege (Heleta 2016:1). Molefe (2016:32) argues, for example, that the curriculum should be decolonised by 'ending the domination of Western epistemological traditions, histories and figures'. This requires a 'fundamental overhaul of the whole epistemological model underlying the current educational system' (Letsekha 2013:9). There is a strong argument that the higher education curriculum cannot merely reflect the colonial and apartheid worldviews (Ramoupi 2014:271), but should be connected to African realities and the lived experiences of black South Africans. If this is not done, the curriculum will continue to reinforce the prejudice that there is not much that one can learn from Africa. The need and motivation for decolonisation - also of the religious education curriculum - is based on the endeavour to redress past inequalities and injustices. Decolonisation is about justice that addresses the epistemic violence of colonial knowledge and colonial thought (Pillay 2015). It aims at eliminating past and current injustices and to reduce injustices in the production of knowledge 
(McKaiser 2016). Césaire (2000:89) argued that decolonisation entails a fundamental change, where the (Ngugi 1981):

[V]alues, norms, customs and worldviews imposed by the colonisers' are rejected. This should be replaced with an approach where Africans see themselves 'clearly in relationship with ourselves and other selves in the universe'. (p. 87)

Decolonisation of the curriculum is thus fundamentally about justice. It requires a fundamental overhaul of, for example, the religious education curriculum. The existing curriculum cannot be changed by merely adding on something (Jansen 2017:160). It asks for a complete rethinking of the curriculum, the decentring (or deterritorialising) of hegemonic Western knowledge (Le Grange 2016:6), with a relational accountability where all parts of the curriculum should be connected (Du Preez 2018:22). In terms of decolonising the religious education curriculum it asks a willingness to lay bare the destructive relation between religion and imperialism and the long-term effects of colonialism (Gearon 2002:146). It is in this regard where the history of Christianity as 'crusaders in the "old" world [and] conquistadors in the "new"' should be kept in mind. It should be acknowledged, for example, that 'the missionary arm of British imperialism came close to totally destroying the cultural and religious identity of millions of colonised people' (Villa-Vincencio 1999:19). In the name of God, the Trinity, Christians conquered and colonised. ${ }^{5}$ The concept of the Trinity operated in the service of colonisation (Conradie \& Sakupapa 2018:39). The Christian missionaries' concept of God as a Trinity displaced to a large extent the original or traditional concept of God in the colonies. The concept of the Trinity - as the name of the Christian God thus became a symbol of colonisation and even oppression (see the next section) to those being colonised.

If decolonisation requires a fundamental overhaul of the religious education curriculum (as argued here), the concept of the Trinity (the name and doctrine of the Christian God) should be decolonised. To continue to use this name in an unproblematic fashion can be similar to reinforcing white and Western dominance and privilege and being insensitive to indigenous African religion, knowledge and spirituality. It can reinforce the prejudice that there is not much that one can learn from Africa; not even about God. The concept of the Trinity is, however, a complex concept and it represents different connotations and associations. This makes any attempt to decolonise the concept of the Trinity a sensitive and potential highly disputed enterprise. Christian Orthodoxy

\footnotetext{
5.This point asks for a more detailed discussion that can only be referred to in the space of this article. A quote by the Catholic missiologist, J. Schmidlin in 1913, can give an indication here of how the mindset of 'to colonise is to missionise', worked. He said, as quoted by David Bosch (1994): 'It is the mission that subdues ou colonies spiritually and assimilates them inwardly ... The state may indeed incorporate the protectorates outwardly; it is, however, the mission which mus assist in securing the deeper aim of colonial policy, the inner colonization'. (p. 306)

6.The close connection between land and spirituality for African people, for example, should be kept in mind here. It was not only their land that was taken away by colonialism but also their sacred places, their spiritual and religious identity. Zake Mda (2000:19) tells a story of the 'sacred waters of the Keiskamma River', in which the wild fig tree that knows all secrets 'for it is directly linked to the ancestors... Who planted it more than hundred years ago' (2000:40), of the stone piles at the crossroads where you add a stone 'for protection of the ancestors for a safe journey' (2000:121), and of 'our rivers and our ocean' for those who belong there (2000:231) Mda (2018:213) argues, therefore, that the search for identity for Africans, is 'no only sentimental; it is emotional and spiritual as well'.
}

may even call this effort of decolonising the concept of the Trinity blasphemous and reject it from the beginning. They might fear, for example, that the decolonisation of the concept of the Trinity might imply a rejection of the triune God for a 'decolonised' god. There are, however, Christian theologians who are willing to take on this challenge (like Conradie and Sakupapa), because - as they argue - decolonisation fits the redemptive nature of the Christian God.

\section{The concept of the Trinity: Colonising and oppressive or decolonising and redemptive?}

The Trinity can be described as the traditional faith expression in Christianity (Bentley 2017:6), or - according to the Trinitarian theologian Jenson (2010:35) - as a 'maximally compressed version of the one God's particular story'. The Trinity is the 'most proper' naming of the absolute, the identity of the particular revelation of God within Christianity (Verhoef 2019:1). 'Father, Son and Holy Spirit' is the specific Christian name for God, the 'historical particularity of God's identity' (Peters 1998:343). Thus, the concept of the Trinity is part of the age-old Christian tradition and theology and in this sense it might be a symbol of hope, love and joy.

The concept of the Trinity is, however, also associated with Western missionaries and colonialism (e.g. missionaries during Dutch and British colonial periods in South Africa), ${ }^{7}$ and in that sense it became a symbol of oppression, imperialism, colonisation, destruction and hopelessness. ${ }^{8}$ As part of classic theism it is often critiqued by women, Black people and poor people as inherently violent (eds. Venter \& Tolmie 2012:149). The name and doctrine of the Trinity, therefore, are ambiguous in terms of associations and interpretations. Conradie and Sakupapa (2018:37) pick up on this when they ask the question if one should 'decolonise the doctrine of the Trinity' or whether the doctrine of the Trinity should be understood as decolonising. The first implies the negative association with the name but the second implies that decolonisation is understood as the inherent quality of the Trinity itself - as the God who brings freedom and justice by being Trinitarian.

Conradie \& Sakupapa (2018:51) acknowledged the fact that the Trinity has been used 'to legitimise colonial rule and to suppress indigenous spirituality', but they nonetheless investigate whether the doctrine of the Trinity can be retrieved in the context of contemporary debates on decoloniality. They first explore two approaches to decolonisation of the concept of the Trinity, before they investigate the counter-position, namely the doctrine of the Trinity as decolonising. The first approach to decolonising the doctrine of the Trinity, which they explore, may be described as continuity (between ATR

7.David Bosch (1994) discusses this in detail in his authoritative book Transforming Mission (see especially pages 226-230). He argues thoroughly, with detailed examples, how 'colonization and Christianization not only went hand in hand but were two sides of the same coin' (1994:275).

8.John De Gruchy (2002:200) argues, therefore, in agreement with Boesak, that 'repentance for misusing God's name in oppressing others is necessary...'. 
and Christianity), whilst the second approach may be described as discontinuity.

The first approach is to decolonise the doctrine of the Trinity by African Christian theologians, in such a way that it remains a continuation of Christianity. This approach becomes visible in contemporary African Christian theologians' apparent lack of interest in the doctrine of the Trinity (Conradie \& Sakupapa 2018:38). This lack of interest is because of their wish to maintain a continuity between the Supreme Being of ATR and the Christian identity of God. The lack of interest in the doctrine of the Trinity is a way for African Christian theologians to underplay the Christian confession of Jesus as divine, in order to emphasise the continuity between ATR's Supreme Being and God as Father in the Bible. Hence, the concept of the Trinity is not so much decolonised, but rather under-emphasised (even ignored) in an attempt to link ATR's concept of God to that of Christianity's concept or doctrine of the Trinity.

A decolonisation of the concept of the Trinity is, however, achieved in the sense that the Trinity is implicitly reformulated - away from the dogmatic Western understanding thereof as Trinitarian - to the African understanding thereof as only one god (as the Supreme Being) and not as three-in-one. ${ }^{9}$ The reformulation is implicit in their apparent lack of interest in the doctrine of the Trinity, but it becomes more explicit in their emphasis on God the Father and other concepts that emphasise the oneness of God. These African Christian theologians, such as Mbiti (2013) and Idowu (1973), for example, asserted a universal notion of God as the Supreme Being, although they still emphasised the continuation with the Christian God. There is no clear discontinuity with Christianity, but rather a definite degree of continuity that is articulated in various ways (Sakupapa 2018). This process of conceptual decolonisation (Wiredu 1998:23) argues for a continuation between ATR and Christianity.

The problems with this first approach to the decolonisation of the doctrine of the Trinity - of continuity - are firstly that ATR is in this process reduced to preparation evangelico. This means that Africa's pre-Christian religious heritage only prepared African people for the gospel and it does not have any other worth now or in itself. Secondly, the notion that there is (or should be) real continuation between ATR and Christianity, is problematic. It is doubtful that the Supreme Being of ATR has the same divine identity as the God of redemption as proclaimed in the Christian tradition (Conradie \& Sakupapa 2018:41). Consequently, this approach to decolonising the concept of the Trinity may only pretend to have a continuation with ATR, whilst ATR might actually be reduced to preparation evangelico. The clear choice to have a continuity with Christianity might even be understood as a continuation and support of the underlying structures of oppression and injustice that are embedded within society

9The doctrine of the Trinity was the result of centuries of deliberations at synods of the early Church. The debate here, between the African understanding of ' and the Western and the Western understanding of the 'Trinity', can be read to some extent as continuation of the initial deliberations about the doctrine of the Trinity, but now in a new cultural-political context. through the coloniality of Christianity. As such, this approach to decolonising the concept of the Trinity is found wanting. It remains highly problematic because the Western dominance remains. For this reason, other African theologians argue that discontinuity is a better approach.

The second approach to decolonise the concept of the Trinity is to emphasise the Supreme Being of ATR in such a way that there is discontinuity with Christianity and as per implication a rejection of the concept of the Trinity altogether. In this approach of decolonisation there is a resistance amongst African scholars and theologians to reinterpret the Christian concept of God (the Trinity) in terms of ATR. They argue that such a reinterpretation will marginalise African religions (or reduce it to preparation evangelico as explained here). The discontinuity between ATR's Supreme Being and the Trinity is stressed because the concept of the Trinity 'operates in the service of colonisation' (Conradie \& Sakupapa 2018:39). This discontinuity approach is stressed by non-Christian African scholars, most notably by the Ugandan poet and scholar p'Bitek (2011:22). He described African Christian theologians as 'intellectual smugglers' who robed African deities with Hellenistic garbs (Conradie \& Sakupapa 2018:43). This is also the critique offered by authors such as Fanon and Biko. Biko does, however, leave some room for continuity when he argues that Black Christians should construct a black theology, but there is a strong argument for an own identity and Black consciousness in this process. p'Bitek's much more radical critique involves a decolonial critique of Christianity as a colonising religion (Conradie \& Sakupapa 2018:44), but African theologians have not yet thoroughly engaged with this critique (Bediako 1999:438), as in the case of Biko's, for example.

The obvious problem with decolonising the doctrine of the Trinity in this second approach of discontinuity, is that decolonisation amounts to the rejection of the concept of the Trinity and the Christian religion. African traditional religion is positioned next to Christianity as at least an equal religion with the potential of religions (and Gods) in conflict (or at war). This second approach to decolonising the concept of the Trinity is thus more thorough in its rejection of underlying colonialist structures, but it creates problems in terms of religious tolerance, diversity and freedom, inter-religious and multifaith dialogue and the potential to celebrate life in all its complexities.

A third approach to decolonising the concept of the Trinity can also be mentioned here. This is a discontinuity position taken by African Evangelical theologians, but in a completely different direction. They argue for a Christianity that is radically discontinuous with ATR. They (Kato, Nyirongo, Adeyemo, Turaki - see Conradie \& Sakupapa 2018:43) argue that ATR offers none or only distorted revelation and salvation (Conradie \& Sakupapa 2018:43) and should, therefore, not be continued (or integrated) in one's thinking and acceptance of Christianity. Here we find a total neglect of any decolonisation of the Trinity or Christianity and a disregard for a possible positive contribution of ATR. 
The different approaches to decolonise the concept of the Trinity include (1) a discontinuity with Christianity and a mere return to ATR (e.g. p'Bitek), (2) the continuity with Christianity as a sort of middle position where there are various degrees of continuation with Christianity (the concept of the Trinity is explained or linked to African cultural concepts, and the concept of the Trinity is reinterpreted and connected to ATR's Supreme Being) and (3) no attempt being made to decolonise the concept of the Trinity, with the complete discontinuity with ATR (e.g. by African Evangelical theologians) being promoted.

Conradie and Sakupapa (2018) took a different approach and attempt to retrieve the doctrine of the Trinity in the context of contemporary debates on decoloniality. They do this by arguing that the doctrine of the Trinity should be understood as decolonising. They understand decolonisation as the inherent quality of the Trinity itself - as the destabilising force that brings freedom and justice by being Trinitarian. The concept of the Trinity, therefore, does not need to be decolonised. This position appears similar to the African Evangelical theologians who do not see a need to decolonise the concept of the Trinity, but Conradie and Sakupapa develop a different and more nuanced argument, which distinguishes it from the Evangelical position. Conradie and Sakupapa (2018:51) argue for an understanding of the Trinity as a decolonising doctrine and not as an oppressive and colonising one, by firstly indicating that there is no hegemonic notion of the doctrine of the Trinity. The doctrine of the Trinity, as expressed in the Nicene Creed, can, therefore, not be straightforwardly interpreted as dogma. Such an interpretation may lead to a particularist view of the Trinity, which may undermine multifaith dialogue and which stands in opposition to a monotheism, which may allow dialogue with ATR, for example. This is where a mistake is made by, for example, the African (and other) Evangelical theologians, when they assume there is a 'stable doctrinal identity in ecumenical Christianity derived from the Christian creeds that has to be safeguarded against heretical distortions' (2018:51).

Conradie and Sakupapa (2018:51) rather argue for a recognition of the 'counter-hegemonic connotations attached to the three symbols of spirit, cross and father'. A less dogmatic approach is followed here, with the Trinity being understood as symbols and not as persons or a fixed name. These three symbols (or the Trinity then, to translate it back) have the potential to disrupt the power of imperial (or capitalist) forces (2018:52) and in that sense it is decolonising. It is a 'destabilising force that threatens any form of traditionalism, whether Eastern, Western or African in location' (2018:53). Conradie and Sakupapa (2018:53) summarise their argument by concluding that the 'doctrine of the Trinity demonstrates this decolonising movement wherever it is not too readily stabilised as a doctrine'. It is in this vein that I will argue in the last section of this article that the decolonisation of the concept of the Trinity that needs to take place can be done by the deconstruction thereof. This is the alternative approach I propose.

\section{Decolonise or deconstruct?}

To decolonise the concept of the Trinity is to decolonise a concept that is not necessarily stable, fixed and agreed upon in the Christian tradition. ${ }^{10}$ If the concept and doctrine of the Trinity become static and understood in a hegemonic way, it can easily serve a colonising agenda. By taking the work of Conradie and Sakupapa as cue, I will thus argue in this section for the deconstruction of the concept and doctrine of the Trinity and an overall move away from dogmatism. The deconstruction of the concept of Trinity is thus proposed as an alternative approach to the approaches of decolonisation of the Trinity through continuity and discontinuity between Christianity and ATR as discussed here. The motivation for this deconstruction of the concept of the Trinity is not only to allow for decolonisation but it is also motivated by the need for religious freedom, openness and tolerance. Furthermore, it wants to avoid the critique, which Conradie and Sakupapa's 'Trinity as decolonising' may receive, namely that it is too similar to the Evangelical position of complete discontinuity with ATRs and the position where the concept of the Trinity remains the dominant one.

In a previous article on the Trinity and Post-structuralism (Verhoef 2019) I indicated that the concept and doctrine of the Trinity is fundamentally part of the historical resources of Christianity, without which philosophical theology runs the risk of 'becoming empty' (Gregersen 2013:417). For the Trinitarian theologian Robert Jenson, God is Trinity because of God's involvement through history, through the father, son and spirit, which belongs essentially to the life of the one God. God is thus identified as Trinity through this historical involvement, through 'his story', and it is not the outcome of some abstract debate regarding how three can be one or vice versa (Verhoef 2008:235). These theologians argue that the concept Trinity is crucial in identifying the Christian God, but the critique of deconstruction and post-structuralism cannot be ignored here. This would create the risk of lapsing into a sort of post-modern fideism, a hegemonic dogmatism and/or 'apathetic pluralism' (Schrijvers 2016:4). Some of the dangers of such a position in terms of colonisation have been spelled out here.

The critique of deconstruction and post-structuralism - that God is the 'infinite desertification of language' (Derrida 1995:55-56; Meylahn 2016:4), unknowable and unnameable - should be taken seriously for at least the sake of decolonisation of religious education in general and for the decolonisation of the concept Trinity in particular. How are we then to think about the critique and implications of deconstruction and post-structuralism, and the particularity and naming of the Trinity within the context of decolonisation?

Post-structuralism, especially as developed in the deconstructionist theories of Jacques Derrida, posits that

10.This article does not focus on the historical development of the doctrine of the Trinity, but as mentioned in a previous footnote, there was a long struggle during the early years of the Church to come to a suitable formulation of the doctrine. This article represents to some extent another phase in that struggle. 
language is not a transparent medium that connects one directly with a 'truth' or 'reality' outside language, but that we remain in language as a structure or code (Verhoef 2019:2). The starting point of deconstruction is that the real, the given, is unavailable. It is always beyond what we know (Wisse 2010:68). Derrida argued that all that we have is a trace: no finality is given in language about the final meaning or about that which is signified by the signifier, so that language itself is always trapped within this endless referencing. This structure of language and signification is described by Derrida as the representational dimension of différance - a play on the fact that the French word différer means both to defer and to differ. Derrida famously argued that 'there is nothing outside the text [there is no outside-text; il n'y a pas de horst-text]' (1997:158). Thus, 'there is nothing outside of the text to which one can have access without language, which is not also text' (Meylahn 2012:1). The implication of différance is that a deferral (referral, postponement) of meaning takes place, that naming is contentless, and that we have a 'bottomless collapse, of this endless desertification of language' (Derrida 1995:56-57).

The implication of this deconstructionist theory of Derrida for religion is that religion is without commitment to or identification with any particular concrete religion or god. To name God (e.g. as Trinity) is only possible in religious discourse, God-talk or theopoetics, which admits not to logic (theologic), but to (Caputo 2014):

$[A]$ poetics of what stirs within the name of God, within what 'we' call 'God'. As these quasi-phenomenological forms of theopoetics never reach the stasis of a fundamental Absolute reality, one must acknowledge that religion is Vorstellungen all the way down!. (p. 52)

Theopoetics should, however, not only be negatively assessed. Meylahn (2012:8) observes that it brings a 'vulnerable inconclusivity and an active expectant openness', which might help theology 'to steer away from "theopoetry" (absolute knowledge; fundamentalism) and "theopolitics" (a battle of the gods) which is often found in metaphysical theology' (Verhoef 2017:177). Theopoetics makes it challenging, but not impossible to think about Christianity (specifically the Trinity) in this context of post-structuralism. The 'transcendental signifier' is lost, but it is still possible to 'move out of sterile debates of endless deconstruction' (Schrijvers 2016:xi). To do that, asks for a more playful approach to our beliefs.

To explain this differently: Christianity (and per implication the Trinity) is (Schrijvers 2016):

$[A]$ name for a historical set of beliefs that is always but a historical construction (and, therefore, subject to change and deconstruction). Christianity is immersed in the deconstructive play of the traces, where what we are trying to name can only ever be named inappropriately. (p. 133)

Consequently, there is no absolute, no name (e.g. Trinity) that lies outside the 'system of Christianity'. This makes it a 'weak' religion, or a 'religion without religion' (Caputo 1997:161-181).
The religion is 'weak' because no absolutes can be named, no sovereign power is claimed and there is no dictatorship of religion. To deconstruct the concept of the Trinity is thus a way to move to a more playful understanding of Christianity (and religion per se). It entails a process where the concept of the Trinity is not destructed, but rather taken apart, disassembled and loosened up 'in order to give some play to the possibility from which it emerged but which it, qua assembled structures, hides' (Nancy 2008:148). So, with the transcendental signifier 'lost', everything is not lost. It is a recognition that although God cannot be named in absolute terms (e.g. Trinity), the playful and imaginative identification of God opens up possibilities of life, love and hope. It is a move away from using religious language, dogmas or creeds to confess one's faith, to a graceful acceptance and celebration of the wonders of life - to find hope, love and meaning on a very mundane, corporal and immanent level and not in metaphysical 'truths'. It is thus a move away from 'the threeheaded monster of metaphysics - the Omni-God of omnipotence, omniscience and omnipresence - and the "triumphalist teleologies and ideologies of power" that it has provoked' (Manoussakis 2006:xvi). In this sense the deconstruction of the concept of the Trinity leads to the decolonisation of the Trinity. The Trinity can then, for example, be understood as symbols (as Conradie and Sakupapa argued), rather than as a static doctrine and dominant dogma associated with colonialism and oppression.

The deconstructing of the concept of the Trinity is fundamental to decolonising the concept of the Trinity. A post-structuralist imagining of the concept of the Trinity challenges absolute beliefs, patriarchy and power structures in religious symbols and concepts, so that the connection between power (coloniality) and religion (e.g. the concept of the Trinity) is undermined. It then also applies to the beliefs of ATR, of course, and it brings a playfulness to that as well. Deconstruction has the further implication of challenging the static and dogmatic beliefs about the concept of decolonisation itself. Decolonisation cannot and should not become static, dogmatic and eventually oppressive. Here, one also needs to find a more open and playful approach to beliefs, which may provide a hopeful and just vision of life. This is the position I advocate, although I am aware that some people will argue that this position is too relativistic and others will cherish a nostalgic (or even dogmatic) retention of a doctrine and concept of the Trinity that secures them some 'finality and firmness' of their religious beliefs.

\section{Conclusion}

The focus of this article was on the need to decolonise the concept of the Trinity and on different approaches to achieve it, in an effort to decolonise the religious education curriculum. I argued that in order to decolonise the religious education curriculum, the concept of the Trinity should be decolonised. In other words, if we continue to speak of the Trinity in an unproblematic fashion in the religious education curriculum (especially in relation to ATRs), we may reinforce white and Western dominance and privilege, whilst being 
insensitive to indigenous African religion, knowledge and spirituality. Decolonisation requires a complete rethinking of the curriculum, the decentring (or deterritorialising) of hegemonic Western knowledge and in that sense one needs to rethink the concept of the Trinity as well - especially in relation to ATRs.

All the different approaches to decolonising the concept of the Trinity have certain problems, and the process can easily end up with the binary and oppositional thinking of either continuity (between ATRs and Christianity) or discontinuity. A third option of understanding the Trinity as decolonising tries to escape this impasse, but may also be criticised as a move back to the dominance of the Trinity in relation to ATRs concepts of the Supreme Being. I therefore proposed an approach of decolonising the concept of the Trinity through deconstruction as an alternative to all these approaches. I propose this, because to deconstruct the concept of the Trinity is a way to move to a more playful and lively understanding of Christianity (and religion per se). It is not done in an effort to retain the doctrine of the Trinity, but rather as a recognition that God cannot be named in absolute terms (e.g. Trinity or One Supreme Being), and that a more open, fluid and imaginative identification of God is needed. It accordingly asks for a move away from religious language and creeds understood as dogmas or 'final truths', to a more modest (and less powerful and potential oppressive) approach to truth, life and others. It celebrates the wonders of life on a very mundane, corporal and immanent level and not in the transcendent and metaphysical.

This deconstruct-to-decolonise-approach has various implications for the decolonisation of the religious education curriculum. ${ }^{11}$ In the first instance it is an approach that does not only question and decolonise the concept of the Trinity, but it is also applicable to other religions, other concepts and other names of God. In this sense it promotes an openness and playfulness within religious discussion, without trying to reject religion's effort to find hope, love and meaning in life. Through theopoetics, for instance, it resists an approach to religion where one may easily get stuck with oppositional truth claims (absolute knowledge; fundamentalism) and may end up in a 'battle of the gods', as is so often found in metaphysical theology. Another implication for decolonising the education curriculum is that all these concepts decolonisation, education and curriculum - can (and should) also be approached in less dogmatic and potentially oppressive ways. All these concepts can be deconstructed as well. An openness and playfulness should, therefore, remain in the process of decolonising the religious educational curriculum, in order to celebrate diversity within education, with a sensitivity for the constructive and destructive potential of religions in general.

11.I do not understand education in general, and religion education specifically, as something that needs to be motivated or justified in terms of externa (transcendent) goals such as a just society, responsible citizenship ethics and/or (transcendent) goals such as a just society, responsible citizicin (2019), Toward/or religious notions. I agree with Joris Vieghe and Piotr Zamojski (2019), Towards an Ontology of Teaching, who a fully immanent view' (2019:63) of education. As I argued elsewhere, 'the autotelic nature of education should be appreciated and should be informed by [a] flattened ontology' (Verhoef \& Du Preez 2020:150). Such an understanding of education can open up various possibilities for religious education specifically.

\section{Acknowledgements Competing interests}

The author has declared that no competing interest exists.

\section{Author's contribution}

I declare that I am the sole author of this research article.

\section{Ethical considerations}

This article followed all ethical standards for a research without direct contact with human or animal subjects.

\section{Funding information}

The author gratefully acknowledges the National Research Foundation for providing a research grant (No. 119452) for conducting this study.

\section{Data availability}

Data sharing is not applicable to this article as no new data were created or analysed during this study.

\section{Disclaimer}

The views and opinions expressed in this article are those of the authors and do not necessarily reflect the official policy or position of any affiliated agency of the authors.

\section{References}

Bediako, K., 1999, Theology and identity: The impact of culture upon Christian Thought in the second century and in Modern Africa, Pegnum Books, Oxford.

Bentley, W., 2017, 'How postmetaphysical can God-talk be?', HTS Teologiese Studies/ Theological Studies 73(3), a4669. https://doi.org/10.4102/hts.v73i3.4669

Biko, S.B., 2017, I write what I like: Selected writings, Picardo Africa, Johannesburg.

Bosch, D.J., 1994, Transforming Mission. Paradigm shifts in theology of mission, Orbis Books, New York, NY.

Caputo, J.D., 1997, The prayers and tears of Jacques Derrida: Religion without religion Indiana University Press, Bloomington, IN.

Caputo, J.D., 2014, 'Response by John D. Caputo: One slight tweak', in Crockett, Putt \& Robbins (eds.), The future of continental philosophy of religion, pp. 51-58, Indiana University Press, Bloomington, IN.

Césaire, A., 2000, Discourse on colonialism, Monthly Review Press, New York, NY.

Conradie, E.M. \& Sakupapa, T.C., 2018, “'Decolonising the Doctrine of the Trinity” or "The Decolonising Doctrine of the Trinity"?', Journal of Theology in Southern Africa 161(1), 37-53.

De Gruchy, J.W., 2002, Reconciliation. Restoring Justice, Fortress Press, Minneapolis, MN. Derrida, J., 1995, 'Sauf le nom', in J. Derrida \& T. Duoit (eds.), D. Wood, J.J. Leavey \& I. McLeod (transl.), On the name, pp. 35-88, Stanford University Press, Stanford, CA. Derrida, J., 1997, Of grammatology, G.C. Spivak (transl.), John Hopkins, Baltimore, MD.

Du Preez, P., 2018, 'On decolonisation and internationalisation of University Curricula: What can we learn from Rosi Braidotti?', Journal of Education 74(1), 1-13. https:// doi.org/10.17159/2520-9868/i74a02

Du Preez, P. \& Simmonds, S., 2020, 'Reading posthumanism and decolonisation diffractively towards (re)configuring an ontoepistemic approach to religion education', British Journal of Religious Education 43(1), 80-90. https://doi.org/ 10.1080/01416200.2020.1809993

Du Preez, P., Simmonds, S. \& Verhoef, A.H., 2016, 'Rethinking and researching transformation in higher education: A meta-study of South African trends', Transformation in Higher Education 1(1), a2, 1-7. https://doi.org/10.4102/the.v1i1.2

Fanon, F., 2017, The Wretched of the Earth, Kwela Books, Cape Town.

Gearon, L., 2002, 'Human rights and religious education: Some postcolonia perspectives', British Journal of Religious Education 24(2), 140-151. https://doi org/10.1080/0141620020240207

Gregersen, N.H., 2013, 'God, information and complexity: From descriptive to explorative metaphysics', Theology and Science 11(4), 394-423. https://doi.org/ 10.1080/14746700.2013.866475 
Heleta, S., 2016, 'Decolonisation of higher education: Dismantling epistemic violence and eurocentrism in South Africa', Transformation in Higher Education 1(1), a9, 1-8. https://doi.org/10.4102/the.v1i1.9

Idowu, B., 1973, African traditional religion: A definition, Orbis Books, New York, NY.

Jansen, J., 2017, As by fire: The end of the South African University, Tafelberg, Cape Town.

Jenson, R.W., 2010, 'How the world lost its story', First Things 201(1), 31-37.

Kombo, J., 2007, The Doctrine of God in African Christian Thought: The Holy Trinity Theological Hermeneutics, and the African Intellectual Culture, Brill, Leiden.

Le Grange, L., 2016, 'Decolonising the University curriculum', South African Journal of Higher Education 30(2), 1-12.

Le Grange, L., 2018, 'Decolonising, Africanising, indigenising, and internationalising curriculum studies: Opportunities to (re)imagine the field', Journal of Education 74(1), 1-15. https://doi.org/10.17159/2520-9868/i74a01

Letsekha, T., 2013, 'Revisiting the debate on the Africanisation of higher education: An appeal for a conceptual shift', The Independent Journal of Teaching and Learning 8(1), 5-18

Manoussakis, J.P., 2006, After God: Richard Kearney and the religious turn in continental philosophy, Fordham University Press, New York, NY.

Mbiti, J., 2013, Concepts of God in Africa, Acton Press, Nairobi.

McKaiser, E., 2016. Epistemic injustices: The dark side of academic freedom, 2016 DCS Oosthuizen Academic Freedom Memorial Lecture, Rhodes University, Grahamstown, viewed 7 February 2019, from http://www.iol.co.za/news/ epistemic-injustices-the-dark-side-of-academic-freedom-2029747

Mda, Z., 2000, The heart of redness, Oxford University Press, Oxford.

Mda, Z., 2018, 'What it means to be an African', in J.U. Jacobs (ed.), Justify the enemy. Becoming human in South Africa: Zakes Mdla, pp. 203-215, University of KwaZuluNatal Press, Pietermaritzburg.

Meylahn, J.-A., 2012, 'Beyond categories, proper names, types and norms toward fragile openness (Offen-barkeit) of différance, but always from within the text', HTS Theological Studies 68(1), 1-9. Art \#1003. https://doi.org/10.4102/hts. v68i1.1003

Meylahn, J.-A., 2016, 'Non-philosophical Christ-poetics beyond the mystical turn in conversation with continental philosophy of religion', HTS Teologiese Studies/ Theological Studies 72(3), a3542. https://doi.org/10.4102/hts.v72i3.3542

Molefe, T.O., 2016, 'Oppression must fall: South Africa's revolution in theory', World Policy Journal 33(1), 30-37. https://doi.org/10.1215/07402775-3545858

Nancy, J.-L. [2005] 2008, Dis-enclosure: The deconstruction of Christianity, in B. Bergo, G. Malenfant \& M.B. Smith (transl.), Fordham University Press, New York, NY.

Ngugi, W.T.O., 1981, Decolonising the mind: The politics of language in African literature, East African Educational Publishers, Nairobi.

Odora-Hoppers, C. \& Richards, H., 2011, Rethinking thinking: Modernity's 'other' and the transformation of the University, UNISA Press, Pretoria.
Oelofsen, R., 2015, 'Decolonisation of the African mind and intellectual landscape', Phronimon 16(2), 130-146.

p'Bitek, O., 2011, Decolonizing African religions: A short history of African religions in Western Scholarship, Diasporic Africa Press, New York, NY.

Peters, T., 1998, 'God happens: The timeliness of the Triune God', The Christian Century 115(1), 342-344.

Pillay, S., 2015. Decolonising the University, Africa is a Country, viewed 7 February 2019, from http://africasacountry.com/2015/06/decolonizing-the-university/.

Ramoupi, N.L.L., 2014, 'African research and scholarship: 20 years of lost opportunities to transform higher education in South Africa', Ufahamu: A Journal of African Studies 38(1) 269-286.

Sakupapa, T.C., 2018, 'The decolonising content of African Theology and the decolonisation of African Theology', Missionalia 46(3), 406-424. https://doi. org/10.7832/46-3-277

Schrijvers, J., 2016, Between faith and belief: Toward a contemporary phenomenology of religious life, SUNY Press, Albany, NY.

Vahakangas, M., 2002, 'African approaches to the Trinity', in E. Katongole (ed.), African Theology today, pp. 68-93, University of Scranton Press, Scranton, PA.

Venter, R. \& Tolmie, F. (eds.), 2012, Transforming theological knowledge. Essays on theology and the university after apartheid, Sun Press, Bloemfontein.

Verhoef, A.H., 2008, 'How is Robert Jenson telling the story?', Scriptura 98(1), 231-243. https://doi.org/10.7833/98-0-708

Verhoef, A.H., 2017, 'The relevance of continental philosophy of religion for theology in contemporary South Africa', Acta Theologica 37(2), 168-187. https://doi. org/10.18820/23099089/actat.v37i2.10

Verhoef, A.H., 2019, 'Post-structuralism and the Trinity: A reading of The Brand New Testament', HTS Teologiese Studies/Theological Studies 75(1), a5403. https://doi. org/10.4102/hts.v75i1.5403

Verhoef, A.H. \& Du Preez, P., 2020, 'Higher education curriculum transformation in and of radical immanence: towards a free and creative ethics, Alternation. Interdisciplinary Journal for the Study of the Arts and Humanities in Southern Africa, 31:143-163. https://doi.org/10.29086/2519-5476/2020/ sp31a8

Verhoef, A.H. \& Kruger, H., 2019, 'On the decolonisation of operational research: Foundations for further exploration', Indilinga - African Journal of Indigenous Knowledge 18(2), 113-128.

Villa-Vincencio, C., 1999, A theology of reconstruction: Nation-building and human rights, Cambridge University Press, Cambridge.

Vlieghe, J. \& Zamojski, P., 2019, Towards an ontology of teaching. Thing-centred pedagogy, affirmation, and love for the world, Springer, Cham.

Wiredu, K., 1998, 'Toward decolonizing African philosophy and religion', African Studies Quarterly 1(4), 17-46.

Wisse, M., 2010, 'Introduction to the thinking of Graham Ward', in L. Boeve \& C. Brabant (eds.), Between philosophy and theology, pp. 65-72, Ashgate, Surrey. 